\title{
Examining the relationship between finance, institutions and economic growth: evidence from the ASEAN economies
}

\author{
Hazwan Haini ${ }^{1}$
}

Received: 29 March 2019 / Accepted: 2 December 2019 / Published online: 9 December 2019

(C) The Author(s) 2019

\begin{abstract}
This study investigates the role of financial and institutional development on economic growth in the Association of Southeast Asian Nations (ASEAN) economies from 1995 to 2017 using a dynamic panel estimator. Financial development is instrumental in promoting economic growth; however, the effect of financial institutions and financial markets can differ. In recent years, the ASEAN economies have launched financial and institutional integration initiatives towards the goal of an integrated ASEAN Economic Community, which can have a profound impact on economic growth. The estimated results show that financial institutions are positive and significant towards economic growth, while financial markets are insignificant. Equally important, institutional quality plays a significant and positive role in economic growth. More interestingly, the study finds that institutional development is complementary to financial institutions and markets. Member states should emphasise on further financial integration across the ASEAN economies, allowing for the development of financial institutions and markets alongside improvements in institutional quality to increase the effectiveness of financial development.
\end{abstract}

Keywords Economic growth · Financial development · Institutions · ASEAN

JEL Classification E44 $\cdot \mathrm{G} 20 \cdot \mathrm{O} 40 \cdot \mathrm{O} 53$

\section{Introduction}

The ASEAN economies have grown considerably, doubling its share of the world's gross domestic product (GDP) from 3.3 per cent in 1967 to 6.2 per cent in 2016 (World Bank), making it the sixth-largest economic group in the world. In recent

Hazwan Haini

bsmhhb@lboro.ac.uk

1 School of Business and Economics, Loughborough University, Leicestershire LE11 3TU, UK 
years, policymakers in the ASEAN economies are committed to promote further regional integration and growth through the ASEAN Economic Community Blueprint that aims to promote ASEAN as a competitive single market economic region by 2025 (ASEAN Secretariat 2008). An important part of the initiative involves financial development and integration efforts in the region in order to promote further economic growth. In general, there is a consensus that financial development promotes economic growth, through the seminal work by King and Levine (1993) alongside many consequent empirical studies. Financial systems reduce information and transaction costs which allow intermediaries and markets to mobilise savings, allocate resources and facilitate risk management leading to capital accumulation and technological progress for economic growth (Levine 1997). However, a number of studies have suggested that the role of finance in economic growth is weakening and, in some cases, negative, as there may be other factors, such as institutional quality that influences the positive effects of finance on growth (Breitenlechner et al. 2015; Rousseau and Wachtel 2011). Therefore, the initiatives of the ASEAN economies to push financial development and integration make it a compelling study for the examination of the relationship between finance and growth, particularly as there are recent studies that provide evidence against the positive effects of finance.

This study examines several issues regarding the relationship between financial and institutional development to economic growth. First, the study examines the role of finance and institutions in the context of the ASEAN economies from 1995 to 2017 , as the region is understudied in terms of the empirical contribution of finance and institutions to economic growth. The study employs a dynamic panel estimator to control for endogeneity. More importantly, the study distinguishes the extent of the contribution from financial markets and financial institutions. The financegrowth literature has argued that different financial structures, such as the bankbased or market-based financial systems, can be beneficial for economies at different stages of economic development (Cull and Xu 2013; Deidda and Fattouh 2008; Hondroyiannis et al. 2005). The ASEAN economies are a diverse group of countries with varying levels of economic development that includes both developed and developing economies and thus, will be interesting to examine the role of financial structures on economic growth. Finally, the study examines the effects of institutional development on economic growth and its impact on financial development. Many studies have provided evidence of the instrumental role of institutions on economic growth such as the rule of law and governance in an economy (La Porta et al. 1998). As the ASEAN economies are diverse in terms of its economic development, it will be important to examine the contribution of institutional development alongside financial development on economic growth.

The novelty of the study lies in the use of indices to examine the relationship between finance and institution on economic growth. Previous studies that examine the relationship between financial development and economic growth have traditionally employed variables that measure financial depth, such as the ratio of bank credit to GDP for financial institutions (Levine 1997) or the value of stocks traded to GDP for financial markets (Levine and Zervos 1998). This study employs an index of financial institutions and financial markets proposed by Svirydzenka (2016), which considers the depth, accessibility and efficiency of the respective financial structure 
and thus, provides a better measure for overall financial development. In addition, this study employs an index for institutional development proposed from the World Governance Indicators (World Bank). More specifically, the study examines the effects of the rule of law index on economic growth and examines the interaction of this index with the financial structure indices. As a result, this study contributes new evidence on the empirical work on the relationship between finance and institutions to economic growth in the context of the ASEAN economies, which has been understudied. This provides important implications for future policies as the ASEAN economies are committed to developing an integrated ASEAN Economic Community that includes extensive financial and institutional development and integration across the region.

The following sections will be organised as follows. Section 2 provides readers with a brief background on the role of finance and institutions in promoting economic growth, while Sect. 3 reviews the development of the ASEAN economies, focusing on the regional integration policies that the ASEAN has implemented. The econometric model, variables and data sources are discussed in Sect. 4. The estimated results are presented and discussed in Sect. 5. The study concludes in Sect. 6.

\section{Role of finance and institutions in economic growth}

The relationship between finance and economic growth has been discussed for decades. Early theoretical work by Schumpeter (1911) highlights the importance of financial development in spurring economic growth, alongside empirical studies by Goldsmith (1969), and subsequently King and Levine (1993), supported the view that financial development is a good predictor of economic growth. Financial systems consist of intermediaries and markets with functions that promote channels to economic growth through capital accumulation and technological progress (Levine 1997). These functions include acquiring information, exerting corporate governance, managing risk, facilitating exchange and mobilising savings. Thus, financial development is suggested to nurture economic growth through the various functions that financial systems provide. However, financial systems consist of intermediaries and markets which raises the question of which performs the functions more effectively. This led to the debate on the bank-based versus market-based financial system.

Previous researches stressed the advantages that financial intermediaries have over markets in terms of the efficient allocation of capital. Intermediaries are able to finance and exploit economies of scale and scope more effectively in underdeveloped economies and can easily commit additional finance on projects (Stulz 2002). Furthermore, it was suggested that intermediaries outperform a market-based system particularly for developing countries, where intermediaries allow for a more equitable distribution of income (Chakraborty and Ray 2006) and promote physical and human capital investment in poorer countries (Cull and $\mathrm{Xu} 2013$ ). In addition, it is suggested that bank financing supports the growth of smaller firms (Beck et al. 2008), while others emphasise the importance of a strong banking sector in order to reduce information asymmetry between buyers and sellers (Strieborny and 
Kukenova 2015). Finally, although both banks and markets contribute to economic growth, banking development is suggested to be better for long-term economic growth (Arestis et al. 2001).

In contrast, there are researches that argue for the case of a market-based financial system. Theoretically, it is argued that efficient markets are more effective as it reduces the need for investors to research firms as new information will be reflected in public stock prices (Stiglitz 1985). Additionally, banks are more biased towards conservative investments and thus will be less effective at promoting innovation and growth compared to markets (Morck and Nakamura 1999). Furthermore, some dominant banks in developing countries, such as state-owned banks, are less interested in performing financial functions and are more focused on political goals while extracting rents (Rajan 1992). Other research highlights the effectiveness of financial markets in promoting corporate governance, particularly in equity markets through the hostile takeovers of under-performing firms (Scharfstein 1988).

Despite the arguments for an optimal financial structure, the empirical evidence seems to be mixed and there is no consensus for a bank-based or market-based financial system. Early empirical work suggests that both financial structures are positive and significant to economic growth (Levine and Zervos 1998) and emphasise that the aim of financial development is to enhance the functions it performs. Consequent empirical work supported this view and stressed that overall financial development is important as banks and markets can be complementary to one another, allowing for further capital accumulation and technological progress (Huybens and Smith 1999). Banks and markets are suggested to produce different growth paths as markets are more related to long-term financing, while banks are able to finance for both short- and long-term projects (Demirgüç-Kunt and Maksimovic 2002).

However, the differences in the effectiveness of financial structures on economic growth suggests that there may be other factors that can affect this relationship, such as the institutional development of the country. For example, recent research has shown support for stock market development particularly for highly developed countries with strong institutions (Peia and Roszbach 2015). Furthermore, it is also suggested that advanced economies benefit more from market-based financial systems compared to less-developed countries, where bank-based financial systems affect growth more effectively due to lack of access to finance (Cull and Xu 2013). Thus, various researches have argued for the merits of a bank-based and market-based system; however, the lack of consensus suggests that other factors such as institutional development must be considered (La Porta et al. 2008).

Institutions are a loosely based term that includes financial intermediaries and markets, and as such, this study refers to institutions as those that do not include banks and financial markets. Institutions can be defined as human-developed constraints that structure interaction and can be made up of formal and informal organisations with enforcement characteristics (Rodrik 2000). For example, these can range from formal institutions such as political stability, regulatory quality and the rule or law to informal institutions such as cultural norms in social interactions and religion. In theory, formal institutions can provide incentives for agents that can be beneficial for economic growth. An essential institution that is well established in the literature is the rule of law. It is suggested that legal frameworks and origins 
matter can indirectly affect financial development and has a positive effect on economic growth (La Porta et al. 2000). Furthermore, a well-functioning and reliable legal system is crucial in enforcing property rights and other market-oriented institutions to perform effectively for economic growth (Berggren and Jordahl 2005).

Previous studies emphasise the role of the legal system in promoting financial development as enforcement provides protection for investors which promotes further capital allocation and investment (Beck and Levine 2002). More specifically, legal systems reduce moral hazard in both bank-based and market-based systems which ease potential constraints for borrowers to acquire financing (Chakraborty and Ray 2006). On the other hand, empirical studies on the effectiveness of legal institutions are varied as countries experience different growth paths. For example, recent studies find that the effectiveness of legal institutions does not promote stock market development in Sub-Saharan Africa due to the presence of weak legal institutions (Aluko and Azeez 2018). This is important to consider in the case of the ASEAN economies, which consists of a number of developing countries that are undergoing structural changes. Other empirical studies find that economic freedom indices such as an optimal government size, flexible regulations and a strong rule of law can exert beneficial impacts on income (Pattanaik and Nayak 2014). Finally, other empirical studies examine the impact of financial development on institutions, which can indirectly increase growth. Dutta and Mukherjee (2018) suggest that greater financial development can encourage a transparent banking system with strong governance, which increases transparency in the legal environment thus leading to stronger institutional development. As a result, it is important to consider the interaction effects between financial development and institutions as both can have indirect impacts on economic growth.

\section{Development of the ASEAN economies}

The ASEAN economies are a geopolitical and economic organisation established in 1967 by five member states. Today, the organisation is made up of 10 countries that include Brunei Darussalam, Cambodia, Indonesia, Lao PDR, Malaysia, Myanmar, Philippines, Singapore, Thailand and Viet Nam. The aims and purpose of the organisation are to promote and advance economic, social and cultural development through collaborative efforts and initiatives while maintaining peace and stability (ASEAN Secretariat 2008). The ASEAN economies have grown considerably since its inception in 1967, doubling its share of the world's GDP from 3.3 per cent in 1967 to 6.2 per cent in 2016 (ASEAN Secretariat 2018). Furthermore, in 2016, the ASEAN economies as a group have a total young population of 600 million, alongside a high savings rate. As a result, the ASEAN economies display a strong potential to develop further. Despite its strong economic performance, early researches criticised that the growth of the ASEAN economies was mainly driven by capital inputs, which is not sustainable in the long-run, as the effects of capital investments will diminish over time (Krugman 1994). Furthermore, other researches argued that the ASEAN economies depended on external trade, as growth was primarily driven by technological 
progress and transfer through trade openness and foreign direct investment in the region, particularly after the establishment of the ASEAN Free Trade Area in 1993 (Lee and Tan 2006).

However, after the Asian financial crisis in 1997, the ASEAN economies shifted from market-driven institutions to institutional-based regional integration, which was a loose form of regional economic integration as there is an absence of formal cooperative scheme (Nicolas 2008). One of the earliest efforts of financial integration in the region was the Chiang Mai Initiative, which was implemented in 2000 (ASEAN Secretariat 2008). The Chiang Mai Initiative created a network of currency swaps between the ASEAN economies and other neighbouring countries, which provided stability and effectively safeguarded the region from illiquidity and contagion. As a result, financial development in the ASEAN economies was driven by institutional arrangements. In addition to the Chiang Mai Initiative, the ASEAN economies further emphasised on financial stability with the creation of the ASEAN Surveillance Process (Almekinders et al. 2015). In 2003, the ASEAN economies began the development of a regional bond market leading to the creation of the Asian Bond Fund and the Asian Bond Market Initiative, where one addresses demands and the other addresses supply, respectively (Nicolas 2008). However, these financial integration and development efforts still lag behind the financial and monetary integration in the European Union, as the initiatives employed by the ASEAN economies were focused on stability as a result of the Asian Financial Crisis.

In recent years, policymakers in the ASEAN economies have continued to develop initiatives in order to advance the aims and purpose of the organisation. The ASEAN Economic Community Blueprint highlights the region's commitment towards the freer movement of goods and services, attracting foreign direct investment and skilled labour alongside the freer flow of capital (Petri et al. 2012). This can potentially enhance the profile of the ASEAN economies as an important player in the global economy and compete with those of the European Union despite the absence of a shared monetary union and currency. A major initiative discussed within the ASEAN Economic Community Blueprint is the issue of deeper financial integration and development within the region. These include the development of an ASEAN Capital Markets Forum, ASEAN Banking Integration Framework, Working Committee on Capital Account Liberalisation and Working Committee on Payment and Settlement System, which places emphasis on both the integration and development of financial institutions and financial markets (Almekinders et al. 2015).

These initiatives focus on the harmonisation of domestic laws and regulation that can promote regional integration and development leading to the freer flow of capital. In addition, the ASEAN economies emphasise on building financial inclusion and stability measures to reduce inequality and promote overall growth. However, many of these initiatives are still loose when compared to the regional integration efforts such as the European Union. For example, bilateral banking integration is low in the region since domestic banks still dominate the financial systems in the respective ASEAN countries (Almekinders et al. 2015). As a result, the region introduced a framework based on the single passport banks in the European Union in the form of the Qualified ASEAN Bank initiative (Rillo 2018). These regional integration efforts can encourage further financial development as it promotes cross-border 
movement of capital and provides greater market access to the region and ultimately increase economic growth.

Achieving financial development and integration, however, requires liberalisation policies that are sustainable and can mitigate potential risks of credit booms and volatile capital flows. Countries with weak policies and institutions may be vulnerable to the risks of capital account liberalisation and thus, should focus on building strong institutions (Prasad and Rajan 2008). Furthermore, excessive deregulation can increase the frequency of boom and bust cycles (Beck et al. 2014). The ASEAN economies have experienced the Asian Financial Crisis during 1997, where macroeconomic imbalances have reduced capital inflows while capital outflows have caused currencies to depreciate within the region (Thanoon and Baharumshah 2005). The potential risks from financial liberalisation and integration must be mitigated in order to avoid such events. For example, cross-border banking and the integration of regional banks are instrumental in Africa's development, changing its financial system rapidly over the past decade (Beck 2015).

As a result, it is important to understand the financial and institutional landscape of the individual ASEAN member states to evaluate the development of the individual economies. Table 1 presents the financial and institutional development indices for the ASEAN member states. It can be observed that the ASEAN economies are highly diverse in their development of finance and institutions. Unsurprisingly, the least developed ASEAN economies in overall financial development are Viet Nam, Cambodia, Myanmar and Lao PDR with a low rule of law Index. As expected, the four original ASEAN economies, Singapore, Thailand, Malaysia and the Philippines, are

Table 1 Financial and institutional development indices in the ASEAN economies

\begin{tabular}{|c|c|c|c|c|c|c|c|c|}
\hline \multirow[t]{2}{*}{ Country } & \multicolumn{2}{|c|}{$\begin{array}{l}\text { Financial develop- } \\
\text { ment }\end{array}$} & \multicolumn{2}{|c|}{$\begin{array}{l}\text { Financial institu- } \\
\text { tions }\end{array}$} & \multicolumn{2}{|c|}{ Financial markets } & \multicolumn{2}{|c|}{ Rule of law } \\
\hline & 1995 & 2017 & 1995 & 2017 & 1995 & 2017 & 1995 & 2017 \\
\hline Singapore & 0.574 & 0.749 & 0.604 & 0.760 & 0.532 & 0.722 & 1.163 & 1.823 \\
\hline Thailand & 0.440 & 0.699 & 0.483 & 0.738 & 0.387 & 0.645 & 0.463 & 0.044 \\
\hline Malaysia & 0.510 & 0.679 & 0.596 & 0.302 & 0.413 & 0.002 & 0.445 & 0.414 \\
\hline Philippines & 0.323 & 0.392 & 0.297 & 0.395 & 0.342 & 0.380 & -0.002 & -0.414 \\
\hline Indonesia & 0.269 & 0.367 & 0.299 & 0.440 & 0.232 & 0.286 & -0.566 & -0.346 \\
\hline Brunei & 0.384 & 0.329 & 0.597 & 0.470 & 0.164 & 0.181 & 0.739 & 0.647 \\
\hline Viet Nam & 0.202 & 0.290 & 0.255 & 0.428 & 0.145 & 0.145 & -0.559 & 0.070 \\
\hline Cambodia & 0.066 & 0.159 & 0.129 & 0.309 & 0.001 & 0.007 & -1.271 & -1.056 \\
\hline Myanmar & 0.130 & 0.154 & 0.256 & 0.693 & 0.000 & 0.650 & -1.657 & -0.945 \\
\hline Lao PDR & 0.116 & 0.139 & 0.195 & 0.173 & 0.035 & 0.101 & -1.124 & -0.881 \\
\hline
\end{tabular}

Financial development, financial institutions and financial markets indices are compiled from the IMF (Svirydzenka 2016), and the rule of law index is compiled from the World Bank (World Governance Indicators). The financial development, financial institutions and financial markets indices are bounded from 0 to 1, 0 being least developed and 1 at the frontier of development. Further details can be found in Svirydzenka (2016). The rule of law index is bounded between -2.5 and 2.5 , where higher values correspond to better governance. Further details can be found at the World Bank (World Governance Indicators) 
ahead in both finance and institutional development. Thus, it is important to consider that the economies are at different stages of development when implementing policies for regional integration, as the developed economies will benefit more than their lessdeveloped counterparts. On the one hand, the overall level of financial and institutional development shows an improvement from 1995 to 2017. This suggests that the loose regional integration policies implemented by the ASEAN economies may be effective in the region.

Thus, it is suggested that there are important prerequisites that must be in place before financial reforms and integration can be successful, which includes institutional reform, stable macroeconomic environment, policy credibility and effective and adequate monetary supervision (Fowowe 2013). Similarly, recent research has emphasised the role of institutional quality in promoting economic growth in the ASEAN economies (Masron 2017). Interestingly, developing strong financial institutions can promote transparency which leads to a positive feedback effect on economic growth, as a more transparent economy attracts higher levels of foreign direct investment (Dutta and Mukherjee 2018). Hence, it is essential to investigate and understand the role of financial and institutional development in economic growth, in order to identify appropriate policies that can accelerate the goals of the ASEAN Economic Community Blueprint.

\section{Empirical methodology}

The following section discusses the econometric model employed and provides a discussion on the justification of the variables employed and the data sources.

\subsection{Dynamic panel estimator}

There are numerous methods to examine the effects of finance and institutions on economic growth. This study examines the ASEAN economies over a sample time period, and thus, panel analysis is appropriate in this case. Many previous empirical studies examining economic growth employ a Barro (1991) or Mankiw et al. (1992) styled regression, while others empirically examine growth by differentiating a Cobb-Douglas production function. In similar vein to previous studies investigating growth, this study employs a translog production function augmented with finance and institutional variables that allows the model to be parsimonious and provides stronger inferences (Haini 2019). This differs from many previous studies in a number of ways. The translog production function reflects the factors of production, such as capital and labour, and allows for the flexibility to augment other variables of interest such as financial and institutional variables that can be embodied in the factors of production.

$$
Y=A K^{\beta} L^{1-\beta}
$$


Consider Eq. (1), which presents the production function in levels (upper-case letters) where $Y$ represents output gross domestic product (GDP), $K$ and $L$ represent inputs capital and labour, respectively. $A$ and $\beta$ are a vector of parameters.

$$
y=\alpha+\beta k+\varepsilon
$$

Equation (1) can be re-written and log-transformed to produce Eq. (2), by dividing $y$ and $k$ by $l$. In Eq. (2), $y$ represents output GDP per labour and $k$ represents capital per labour, while $\alpha$ and $\beta$ are a vector of parameters and $\varepsilon$ represents the error term. The modified translog production function is treated as a Barro (1991) styled regression and allows for the flexibility to augment with other variables of interest.

Meanwhile, Eq. (3) presents the simplified translog production function model in panel form, where the observations are measured across $i$ th country and at time $t$. The dependent variable, economic growth is represented by $y_{i t}$, while $X_{i t}$ is an exogenous vector of independent variables. The error term $\varepsilon_{i t}$ consists of the countryspecific time-invariant error $\mu_{i}$ and the idiosyncratic error $v_{i t}$, which is assumed to be independent and identically distributed. In addition, $\alpha$ and $\beta$ are a vector of parameters. Equation (3) can be estimated by employing the ordinary least squares (OLS) estimator.

$$
\begin{aligned}
& y_{i t}=\alpha+\beta X_{i t}+\varepsilon_{i t} \\
& \varepsilon_{i t}=\mu_{i}+v_{i t}
\end{aligned}
$$

The OLS estimator is relatively simple and straightforward and provides a baseline of results for comparison. However, the OLS estimator can result in an upward or downward bias, as $\mu_{i}$ is unobserved and may be positively or negatively correlated with the independent variables. As a result, there are other panel estimators that can be employed in order to control for endogeneity and provide more efficient estimates. Hence, this study employs a dynamic panel estimator, namely the system GMM estimator to control for endogeneity (Blundell and Bond 1998).

$$
\Delta y_{i t}=\beta \Delta X_{i t}+\gamma \Delta y_{i, t-1}+\Delta \mu_{i t}
$$

The dynamic panel estimators builds on Eq. (3), where it includes the lagged dependent variable $y_{i, t-1}$ as an independent variable. This is shown in Eq. (4), with $\gamma$ as a vector of the parameter. Additionally, the system GMM considers the first differences of Eq. (3) to produce Eq. (4) and eliminate the country-specific timeinvariant error $\mu_{i}$. More importantly, taking first differences effectively eliminates instruments at period $t=1$ and $t=2$ and therefore, the system GMM moment conditions in Eq. (5) is as follows:

$$
\begin{array}{ll}
E\left[y_{i, t-s},\left(\mu_{i, t}-\mu_{i, t-1}\right)\right]=0 & \text { for } s \geq 2 ; \quad t=3, \ldots, T \\
E\left[X_{i, t-s},\left(\mu_{i, t}-\mu_{i, t-1}\right)\right]=0 & \text { for } s \geq 2 ; \quad t=3, \ldots, T
\end{array}
$$

Furthermore, the system GMM estimator extends the moment conditions, as differencing can provide biased estimates, where the instruments can potentially exhibit random walk or are persistent over time (Blundell and Bond 1998). As a result, the 
system GMM estimator employs both differences and levels as instruments and the moment conditions in Eq. (5), alongside additional moment conditions presented in Eq. (6).

$$
\begin{array}{ll}
E\left[\left(y_{i, t-s}-y_{i, t-s-1}\right)\left(\mu_{i}-\mu_{i, t}\right)\right]=0 & \text { for } s=1 \\
E\left[\left(X_{i, t-s}-X_{i, t-s-1}\right)\left(\mu_{i}-\mu_{i, t}\right)\right]=0 & \text { for } s=1
\end{array}
$$

The system GMM estimator is estimated using a two-step procedure, and the estimated results also provide robustness and sensitivity of the coefficients as both estimators should report comparable results. The study reports the robustness of the instruments using the Sargan's $J$-test of instrument validity and overidentifying restrictions (Sargan 1958). In addition, the Arellano-Bond test of serial autocorrelation is reported, in order to satisfy the moment conditions imposed in Eqs. (5) and (6), with the null hypothesis of no autocorrelation at the second order (Arellano and Bond 1991). The full estimated model specification and variables are discussed in the following section.

\subsection{Data sources and variables employed}

This study employs annual-level data from a balanced panel data set of ten ASEAN countries namely Brunei, Cambodia, Indonesia, Lao PDR, Malaysia, Myanmar, Philippines, Singapore, Thailand and Viet Nam from the period of 1995-2017. The sample countries were chosen as the ASEAN economies have shared aims and objectives through regional integration. Additionally, the sample time period was chosen based on data availability. The data for the variables are compiled from various sources namely the Penn World Table 9.1 (Feenstra et al. 2015), World Development Indicators (World Bank), World Governance Indicators (World Bank) and the IMF Financial Development Index Database

Table 2 Summary statistics

\begin{tabular}{lllrrrr}
\hline Variable & Definition & Source & Mean & SD & Min. & Max \\
\hline$y$ & Real GDP (mil.) per labour & PWT & 0.039 & 0.054 & 0.002 & 0.206 \\
$k$ & Real capital stock (mil.) per labour & PWT & 0.151 & 0.199 & 0.001 & 0.655 \\
fi & Financial institutions index & IMF & 0.399 & 0.180 & 0.081 & 0.760 \\
fm & Financial markets index & IMF & 0.296 & 0.245 & 0.000 & 0.903 \\
law & Rule of law index & WGI & -0.244 & 0.888 & -1.791 & 1.825 \\
opn & Ratio of imports and exports to GDP & WDI & 1.188 & 0.171 & 0.819 & 1.520 \\
pop & Population density per 1000 m² & WDI & 779.120 & 1979.459 & 20.999 & 7915.730 \\
hc & Human capital index & PWT & 2.291 & 0.491 & 1.438 & 3.974 \\
\hline
\end{tabular}

$I M F$ International Monetary Fund, WGI World Governance Indicators, WDI World Development Indicators

$N=230$ observations from the ASEAN economies from 1995 to 2017. The statistics presented are in levels and prior to $\log$-transformation. PWT refers to Penn World Table 9.1 
(Svirydzenka 2016). The variables employed are summarised in Table 2, while Eq. (7) represents the specification of the estimated model.

$$
\begin{aligned}
y_{i t}= & \alpha_{i t}+\beta_{1} k_{i t}+\beta_{2} t_{i t}+\beta_{3} \mathrm{fi}_{i t}+\beta_{4} \mathrm{fi}_{i t}^{2}+\beta_{5} \mathrm{fm}_{i t}+\beta_{6} \mathrm{fm}_{i t}^{2}+\beta_{7} \operatorname{law}_{i t} \\
& +\beta_{8}(\mathrm{fi} \times \text { law })_{i t}+\beta_{9}(\mathrm{fi} \times \text { law })_{i t}+\beta_{10} \mathrm{opn}_{i t}+\beta_{11} \mathrm{pop}_{i t}+\beta_{12} \mathrm{hc}_{i t}+\varepsilon_{i t}
\end{aligned}
$$

As the study examines the relationship between financial and institutional development to economic growth using a translog production function, GDP per labour denoted by $y_{i t}$ is the dependent variable. GDP per labour captures economic growth while considering the workforce participation instead of the total population, in line with the production theory. The study also includes capital per labour denoted by $k_{i t}$ as one of the independent variables, consistent with the theory of production, where increased capital stock per labour reflects an increase in investment which can lead to further growth (Solow 1956). The time trend is included to account for Hicks-neutral technical progress as part of the translog production function model. Meanwhile, Eq. (7) also includes other independent variables that include financial structure, institutional development and control variables.

This study employs two financial development variables proposed by Svirydzenka (2016). Traditional variables of financial development generally measure financial depth such as the ratio of M2 to GDP (King and Levine 1993) or the ratio of bank credit to GDP (Levine 1997). Although these traditional variables emphasise the role of financial institutions, they do not take into account the complex nature of financial development. In addition, these variables differ from the traditional marketbased financial development variables used in previous studies of bank-based versus market-based studies (Beck and Levine 2002), which overlooks other dimensions of financial development. As a result, this study employs an index for financial institutions, denoted as $\mathrm{fi}_{i t}$, and an index for financial markets, denoted as $\mathrm{fm}_{i t}$, which allows for the examination of differences in financial structures (Svirydzenka 2016). The indices for financial institutions and financial markets employed are considered to reflect the financial development of an economy in a complete manner, as it considers the depth, accessibility and efficiency of financial institutions and markets.

Previous empirical studies that examine financial structures generally employ variables that reflect financial depth, such as the ratio of private credit to GDP (King and Levine 1993) and stock market capitalisation (Beck and Levine 2002). While this is acceptable, financial development is a multidimensional process and financial sectors have evolved where both financial institutions and markets can capture the essential functions of finance in the economy. In addition to financial depth, the accessibility and efficiency of finance is equally important, as finance that is not accessible will result in opportunity costs, while inefficient financial systems are wasteful (Svirydzenka 2016). As a result, the use of indices provides a more comprehensive variable for financial institutions and markets across the ASEAN economies and will offer a deeper understanding on the role of different financial structures in economic growth. This study also employs the squared terms of financial institutions and financial markets, denoted as $\mathrm{fi}_{i t}^{2}$ and $\mathrm{fm}_{i t}^{2}$, respectively, as a number of recent empirical researches find financial development to be nonlinear (Breitenlechner et al. 2015; Rousseau and Wachtel 2011). 
In addition to the financial structure variables, this study includes an institutional development variable to examine the effects of institutions on economic growth. Similarly, institutional development is a complex multidimensional concept and many previous empirical studies have employed numerous variables to capture the nature of institutions. This study employs an institutional development variable provided by the World Governance Indicators (World Bank), namely the rule of law index, denoted by law $_{i t}$. The rule of law index measures the quality of contract enforcement, property rights, the police and judicial (Kaufmann et al. 2010). It is well established that countries with poor legal institutions do not benefit effectively from financial liberalisation policies and thus, achieve less economic growth (La Porta et al. 1998). Additionally, the rule of law can be employed as a proxy for economic freedom (Pattanaik and Nayak 2014; Santiago et al. 2018). Many previous researches find that economic freedom can foster economic development as marketdriven reforms encourage higher levels of entrepreneurial activity and small-business creation. This is important for the context of the ASEAN economies as many of these economies are undergoing and developing its legal infrastructure. As a result, it will be interesting to examine the effects of the rule of law on economic growth. Furthermore, the study also includes the interaction terms of financial institutions and financial markets with the rule of law, denoted as $(\mathrm{fi} \times \mathrm{law})_{i t}$ and $(\mathrm{fi} \times \mathrm{law})_{i t}$, respectively. This allows for a richer depth of specification and provides better inferences as previous empirical researches suggest that financial development is dependent on the institutional development of an economy (La Porta et al. 1998), while others find that financial development can actually enhance institutional development through encouraging transparency in the banking system (Dutta and Mukherjee 2018).

Lastly, the study employs several control variables that are used in previous growth regressions. The control variable $\mathrm{hc}_{i t}$ represents human capital and is measured using the human capital index proposed by Feenstra et al. (2015). The role of human capital in economic growth is well established in many endogenous growth theories (Romer 1990), and the role of human capital can be complementary to financial development which can promote inclusive growth (Oyinlola and Adedeji 2019). There are empirical issues, however, with the measurement of human capital, as different variables of human capital can provide different results. This study employs a human capital index that captures the multidimensional role of human capital, as it considers the average years of schooling and the rates of return to education (Feenstra et al. 2015). Additionally, the control variables include openness to trade, denoted by $\mathrm{opn}_{i t}$, which measures the ratio of total imports and exports to GDP and population density, denoted by pop $_{i t}$, which measures the population density per $1000 \mathrm{~m}^{2}$. These control variables are used in previous empirical studies that examine the role of trade and population in economic growth (Anwar and Sun 2016; Darku and Yeboah 2018; Haini 2019). The inclusion of these control variables provides a richer understanding of the determinants of economic growth in the ASEAN economies.

The summary statistics of the variables employed are presented in Table 2. It can be observed that the ASEAN economies are diverse in their development over time and across the sample. For example, focusing on the production function variables, 
real GDP per labour across the ASEAN region has an average of 0.039 with a standard deviation of 0.054 , suggesting variance in the development of the ASEAN economies. Likewise, real capital stock per labour also exhibits similar figures with an average of 0.151 and a standard deviation of 0.199 suggesting a high level of variance. It is expected that real capital stock per labour will be positive and significant to the dependent variable consistent with the production theory.

Focusing on the financial development variables, the financial institutions index has an average of 0.399 with a standard deviation of 0.180 suggesting lower levels of variance when compared to the production function variables. As expected, the average financial markets index is lower than the financial institutions index, at 0.296 and also displays a higher level of variance with a standard deviation of 0.245 . Financial institutions such as banks are generally dominant in developing countries, and as a result, it is unsurprising to find that financial institutions are more developed (Rajan 1992). However, the maximum value of the financial institutions and financial markets indices varies. It can be observed that the maximum value of the financial markets index is at 0.903 while the financial institutions index is at 0.760 . This again highlights the diversity of the ASEAN economies, where member states such as Singapore has a developed financial system with both mature markets and institutions.

Meanwhile, focusing on institutional development, the average value of the rule of law index is at -0.244 with a large standard deviation of 0.888 . This variance reflects the commitment of the ASEAN economies to reform throughout the sample time period particularly after the onset of the Asian financial crisis in 1997, where the region began to focus its efforts on institutions-based regional integration (Nicolas 2008). Finally, the control variable openness to trade has an average value of 1.118 , which is expected as many ASEAN economies adopted an export-oriented strategy (Lee and Tan 2006). Population density displays a high level of variation across the region as many of these economies continue to industrialise and urbanise, leading to agglomeration (Nguyen 2018) while the human capital index displays less variation across the sample.

Finally, prior to estimating the system GMM model, all the variables are logtransformed and averaged over 3-year periods. The use of averages focuses on the long-run relationship as the effects of financial development can take time to realise through investment returns over time (Levine et al. 2000). As a result, the use of averages diminishes the effect of short-term shocks and business cycles. More importantly, it justifies the use of the dynamic panel estimator, as averaging the time periods reduces the number of $t$ relative to sample size $n$. This reduces the number of instrumental variables and avoids overidentifying instruments. Lastly, seven sets of regressions are estimated for the system GMM model in order to evaluate the sensitivity of the estimations, which should be broadly similar across the sets of regressions. Set (1) includes the financial institutions index (fi) alongside the control variables, while Set (2) includes fi and its square term $\mathrm{fi}^{2}$. Meanwhile, Set (3) includes the financial markets index (fm) alongside control variables, while Set (4) includes fm and its square term $\mathrm{fm}^{2}$. Set (5) and (6) focus on the interaction terms of fm and fi with the rule of law index (law), while Set (7) includes both the financial development indices and its squared and interaction terms. 


\section{Results and discussion}

This section begins with a brief discussion on the correlation matrix followed by a discussion on the estimated system GMM model coefficients alongside policy implications. The estimated sample correlation matrix is presented in Table 3.

The correlation matrix measures the linear relationship between two variables, where +1 results in two perfectly positively correlated variables, while -1 means two perfectly negatively correlated variables. This provides some understanding of the variables employed and can provide some insight prior to the estimated dynamic panel model. Real capital per labour $(k)$ is associated with real GDP per labour $(y)$, which is expected and is consistent with the production function theory as GDP is a function of capital and labour (Haini 2019). Meanwhile, the other independent variables display a moderate correlation to $y$ with the exception for the rule of law (law). Interestingly, the fi exhibits a stronger correlation with $y$, compared to fm, which suggest that the effects of financial institutions may be more effective in spurring economic growth.

Meanwhile, focusing on fi and fm, the correlation between the two financial development indices is positive and strong. Although both variables are different in nature, as the index for financial institutions focuses on banks, mutual funds, pension funds and insurance, while index for financial markets focuses on stock market size, activity and volumes of government and private debt securities (Svirydzenka 2016). However, both indices can still be highly correlated due to the demand-following hypothesis, which postulates a causal relationship from real growth to financial development, whereby there will be an increase in demand for financial services as the real sector develops (Patrick 1966). As a result, it will be sensible to investigate the role of financial institutions and financial markets in separate specifications in order to examine the contribution of the individual financial structure on economic growth.

The estimated model coefficients of the system GMM estimations are reported in Table 4. The estimated results are robust as they satisfy the conditions of the Arellano-Bond test of no autocorrelation at the second order. Furthermore, the GMM estimations pass the Sargan test for the validity of the instruments. In addition, a

Table 3 Correlation matrix

\begin{tabular}{lllllllll}
\hline Variables & $y$ & $k$ & $\mathrm{fi}$ & $\mathrm{fm}$ & Law & opn & pop & hc \\
\hline$y$ & 1.000 & & & & & & & \\
$k$ & 0.967 & 1.000 & & & & & & \\
$\mathrm{fi}$ & 0.270 & 0.178 & 1.000 & & & & & \\
$\mathrm{fm}$ & 0.144 & 0.174 & 0.683 & 1.000 & & & & \\
law & 0.861 & 0.912 & 0.220 & 0.105 & 1.000 & & & \\
opn & 0.024 & 0.056 & 0.321 & 0.244 & 0.071 & 1.000 & & \\
pop & 0.386 & 0.444 & 0.476 & 0.321 & 0.576 & 0.275 & 1.000 & \\
hc & 0.217 & 0.135 & 0.873 & 0.817 & 0.154 & 0.369 & 0.494 & 1.000 \\
\hline
\end{tabular}

Definition of variables is in Table 2 
Table 4 System GMM model coefficients

\begin{tabular}{|c|c|c|c|c|c|c|c|}
\hline Variables & (1) & (2) & (3) & (4) & (5) & (6) & (7) \\
\hline$y_{i, t-1}$ & $\begin{array}{l}-0.573^{* *} \\
(0.146)\end{array}$ & $\begin{array}{l}-0.202^{* *} \\
(0.290)\end{array}$ & $\begin{array}{l}-0.102 * \\
(0.249)\end{array}$ & $\begin{array}{l}-0.151^{* * *} \\
(0.526)\end{array}$ & $\begin{array}{l}-0.137 * * \\
(0.255)\end{array}$ & $\begin{array}{l}-0.249 * * \\
(0.126)\end{array}$ & $\begin{array}{l}-0.762 * * \\
(0.747)\end{array}$ \\
\hline$k$ & $\begin{array}{l}0.572 * * * \\
(0.028)\end{array}$ & $\begin{array}{l}0.576 * * * \\
(0.028)\end{array}$ & $\begin{array}{l}0.565 * * * \\
(0.028)\end{array}$ & $\begin{array}{l}0.567 * * * \\
(0.029)\end{array}$ & $\begin{array}{l}0.566 * * * \\
(0.028)\end{array}$ & $\begin{array}{l}0.571 * * * \\
(0.027)\end{array}$ & $\begin{array}{l}0.590 * * * \\
(0.028)\end{array}$ \\
\hline$t$ & $\begin{array}{l}0.004^{*} \\
(0.005)\end{array}$ & $\begin{array}{l}-0.002 \\
(0.005)\end{array}$ & $\begin{array}{l}0.007 * \\
(0.004)\end{array}$ & $\begin{array}{l}0.007 * \\
(0.004)\end{array}$ & $\begin{array}{l}0.006 \\
(0.005)\end{array}$ & $\begin{array}{l}0.008^{*} \\
(0.004)\end{array}$ & $\begin{array}{l}-0.002 \\
(0.005)\end{array}$ \\
\hline fi & $\begin{array}{l}0.092 * * \\
(0.050)\end{array}$ & $\begin{array}{l}0.045^{* *} \\
(0.144)\end{array}$ & & & $\begin{array}{l}0.017 * * \\
(0.069)\end{array}$ & & $\begin{array}{l}0.074 * * \\
(0.180)\end{array}$ \\
\hline $\mathrm{fi}^{2}$ & & $\begin{array}{l}0.118^{*} \\
(0.044)\end{array}$ & & & & & $\begin{array}{l}0.213^{*} \\
(0.050)\end{array}$ \\
\hline $\mathrm{fm}$ & & & $\begin{array}{l}-0.005 \\
(0.015)\end{array}$ & $\begin{array}{l}0.011 \\
(0.038)\end{array}$ & & $\begin{array}{l}0.051^{*} \\
(0.020)\end{array}$ & $\begin{array}{l}0.032 * \\
(0.039)\end{array}$ \\
\hline $\mathrm{fm}^{2}$ & & & & $\begin{array}{l}0.001 \\
(0.003)\end{array}$ & & & $\begin{array}{l}0.005 \\
(0.003)\end{array}$ \\
\hline law & $\begin{array}{l}0.024 * \\
(0.071)\end{array}$ & $\begin{array}{l}0.022^{*} \\
(0.071)\end{array}$ & $\begin{array}{l}0.023^{*} \\
(0.072)\end{array}$ & $\begin{array}{l}0.024 * \\
(0.073)\end{array}$ & $\begin{array}{l}0.040 * * \\
(0.119)\end{array}$ & $\begin{array}{l}0.039^{*} \\
(0.086)\end{array}$ & $\begin{array}{l}0.052^{*} \\
(0.119)\end{array}$ \\
\hline (fi × law) & & & & & $\begin{array}{l}0.018^{*} \\
(0.107)\end{array}$ & & $\begin{array}{l}0.013 * * \\
(0.132)\end{array}$ \\
\hline$(\mathrm{fm} \times$ law $)$ & & & & & & $\begin{array}{l}0.092^{*} \\
(0.029)\end{array}$ & $\begin{array}{l}0.010^{*} \\
(0.036)\end{array}$ \\
\hline opn & $\begin{array}{l}0.113^{* *} \\
(0.066)\end{array}$ & $\begin{array}{l}0.118^{*} \\
(0.065)\end{array}$ & $\begin{array}{l}0.136^{*} \\
(0.065)\end{array}$ & $\begin{array}{l}0.136^{* *} \\
(0.065)\end{array}$ & $\begin{array}{l}0.086^{*} \\
(0.067)\end{array}$ & $\begin{array}{l}0.070^{*} \\
(0.067)\end{array}$ & $\begin{array}{l}0.038^{*} \\
(0.065)\end{array}$ \\
\hline pop & $\begin{array}{l}0.061 \\
(0.226)\end{array}$ & $\begin{array}{l}0.384^{*} \\
(0.253)\end{array}$ & $\begin{array}{l}-0.082 \\
(0.215)\end{array}$ & $\begin{array}{l}-0.096^{*} \\
(0.217)\end{array}$ & $\begin{array}{l}-0.082 \\
(0.240)\end{array}$ & $\begin{array}{l}-0.126 \\
(0.211)\end{array}$ & $\begin{array}{l}0.389^{*} \\
(0.262)\end{array}$ \\
\hline $\mathrm{hc}$ & $\begin{array}{l}0.282 * * \\
(0.144)\end{array}$ & $\begin{array}{l}0.207 * * \\
(0.144)\end{array}$ & $\begin{array}{l}0.319 * * * \\
(0.144)\end{array}$ & $\begin{array}{l}0.318 * \\
(0.144)\end{array}$ & $\begin{array}{l}0.380 * * \\
(0.154)\end{array}$ & $\begin{array}{l}0.326^{*} \\
(0.141)\end{array}$ & $\begin{array}{l}0.253 * * \\
(0.151)\end{array}$ \\
\hline Constant & $\begin{array}{l}-2.678^{* *} \\
(1.029)\end{array}$ & $\begin{array}{l}-3.953^{* *} \\
(1.119)\end{array}$ & $\begin{array}{l}-2.138^{* * * *} \\
(0.993)\end{array}$ & $\begin{array}{l}-2.076^{* * * *} \\
(1.005)\end{array}$ & $\begin{array}{l}-2.002 * * * \\
(1.098)\end{array}$ & $\begin{array}{l}-1.857 * * * \\
(0.977)\end{array}$ & $\begin{array}{l}-3.724 * * * \\
(1.152)\end{array}$ \\
\hline$N$ & 70 & 70 & 70 & 70 & 70 & 70 & 70 \\
\hline Wald- $\chi^{2}$ & 1234.77 & 5920.37 & 4990.61 & 4795.67 & 1330.98 & 6262.00 & 9538.9 \\
\hline $\begin{array}{l}\text { No. of Instru- } \\
\text { ments }\end{array}$ & 35 & 35 & 35 & 36 & 36 & 36 & 40 \\
\hline Sargan test & {$[0.281]$} & [0.314] & {$[0.256]$} & [0.895] & {$[0.468]$} & {$[0.742]$} & {$[0.601]$} \\
\hline $\mathrm{AR}(1)$ test & {$[0.001]$} & [0.034] & {$[0.000]$} & [0.041] & [0.043] & {$[0.021]$} & [0.017] \\
\hline $\mathrm{AR}(2)$ test & [0.395] & [0.147] & {$[0.428]$} & {$[0.133]$} & [0.284] & {$[0.401]$} & {$[0.259]$} \\
\hline
\end{tabular}

Definition of variables is in Table 2

$*, * *, * * *$ denote statistical significance at the $10 \%, 5 \%$ and $1 \%$ levels, respectively. SE are in parenthesis (), and $p$ values are in parenthesis []. $N$ is lower than Table 2 as the dynamic panel estimations employ 3-year averages 
production function must have monotonicity properties before it can be reasonably interpreted (Henningsen and Henning 2009). In this case, the translog production variable $k$ is positive and significant to growth at the $1 \%$ level across all seven sets of estimations. The estimated results for $k$ are in line with the production theory and support previous studies that highlight the importance of capital and labour in promoting per capita GDP (Khandker 2016). In fact, Khandker (2016) emphasise that physical capital, labour and technology are more significant in explaining per capita differences in economic growth across countries, even if an economy does not increase trade or liberalise its economy. This is reflected in the estimated findings, as the coefficients of $k$ are large and contributes to more than 55\% of real GDP per labour differences across the seven sets of regressions.

However, when examining the time trend $t$, which reflects technological change over the sample period, it is only positive and significant at the $15 \%$ level in four of the specifications. This suggests that technological change is not a strong driver of real GDP per labour growth in the ASEAN economies. This is interesting as the findings echo the criticisms of previous studies that suggest that the ASEAN economies have grown through capital intensive growth (Krugman 1994). The ASEAN economies must focus on identifying policies that can encourage technological progress, such as developing the human capital stock of an economy or implementing policies that promote innovative activities. These ultimately lead to technological change and sustainable long-run growth. Meanwhile, the estimated results provide some evidence of a convergence effect as it can be observed that the lagged real GDP per labour, $y_{i, t-1}$, is consistently positive and significant across the seven sets of regressions. This suggests that the relatively poorer ASEAN economies are catching up to its wealthier counterparts and support the growth theory of convergence due to diminishing returns (Solow 1956). However, it highlights a slowdown in future growth may be expected, unless technological progress is increased through traditional policy prescriptions of improvements in human capital formation.

Focusing on financial development, the financial institutions and market variables provide interesting results. Financial institutions, fi, are consistently positive and significant to real GDP per labour in Sets (1), (2), (5) and (7). More interestingly, in Set (2), both fi and $\mathrm{fi}^{2}$ are positive and significant, which suggests that financial institutions have a linear relationship to economic growth. This differs from recent studies that show financial development to be nonlinear and exhibit a $U$-shaped curve on economic growth (Breitenlechner et al. 2015; Rousseau and Wachtel 2011). The linear relationship between financial institutions and growth in the ASEAN economies highlights the importance of banking sector in the region and suggests the effectiveness of the current policies implemented in the region (Almekinders et al. 2015). Many previous studies that suggest the nonlinear relationship between finance and growth can be attributed to excessive financialisation and liberalisation in financial markets (Gaffeo and Garalova 2014). Unsurprisingly, the estimated results show that financial markets and its squared term, $\mathrm{fm}$ and $\mathrm{fm}^{2}$, are insignificant to growth in Sets (3) and (4).

Meanwhile, the rule of law, law, is consistently significant and positive to economic growth across all the seven sets of regressions. The rule of law is positive and significant to economic growth, which is expected as the ASEAN economies 
continue to develop as an institutionally sound region. The estimated results support previous studies that emphasise the role of legal institutions in the economy (Haggard and Tiede 2011; La Porta et al. 1998). More interestingly, the positive and significant effect of the rule of law may provide reasons for the differences in the effectiveness of financial structures. Aluko and Azeez (2018) find that legal institutions help explain cross-country differences in stock market development. As a result, the rule of law and overall financial development can be complementary and enhance the quality of contract enforcement and the protection of investors. The rule of law has been a fundamental feature of the ASEAN organisation where member states are committed to develop strong legal institutions to promote regional peace and stability (ASEAN Secretariat 2008). As the estimated results find that the rule of law is positive and significant to economic growth, the ASEAN economies should continue to develop and observe strong governance of legal frameworks and regulation. This can potentially have spillover effects into other sectors, such as the financial markets and institutions in the region which can encourage the efficient allocation of resources for economic growth.

The interaction effect between financial markets with the rule of law, ( $\mathrm{fm} \times$ law), is positive and significant in Set (6), and the interaction effect between financial institutions with the rule of law, $(\mathrm{fi} \times \mathrm{law})$, is also positive and significant in Set (7). The financial markets variable is insignificant in Sets (3) and (4), yet becomes significant and positive in Sets (6) and (7) when it interacts with the rule of law. This supports previous studies that emphasise the growing importance of financial markets, especially when an economy develops sound institutions (Hondroyiannis et al. 2005). Yet the insignificant results also provide an important implication, as it highlights the issue that financial markets across the ASEAN economies still remain fragmented and financial integration efforts are lagging behind when compared to financial institutions (Rillo 2018). Across the ASEAN economies, most of the region have underdeveloped financial markets with the exception of Singapore and as a result, the effects of financial markets may be insignificant as capital markets still remain fragmented, limiting the quality of financial intermediation. The ASEAN economies must continue to integrate its capital markets to facilitate further intra-regional investment flows among the ASEAN economies which can lead to further growth in the region.

Overall, the estimated results present an interesting scenario for the relationship between finance and growth in the ASEAN economies. On the one hand, the estimated results provide support for the role of finance, as the estimated results show that financial institutions are positive and significant to economic growth. This supports previous and recent empirical work that emphasises the role of financial development on economic growth (Ho and Iyke 2018; Sharma and Bardhan 2017). The positive relationship reaffirms the importance of financial development in spurring economic growth for the ASEAN economies despite suffering from a financial crisis during 1997. The positive significance of financial institutions in the region has coincided with the strong commitment of the ASEAN member states in developing a more integrated economic community with strong financial integration efforts (Almekinders et al. 2015). An example of integration 
efforts on financial institutions across the region is the creation of the Qualified ASEAN Banks which follows the European passporting approach for banks.

On the other hand, the estimated results find that the effects of financial markets to be insignificant to economic growth, thus, supporting the literature that postulates the weakening effects of finance on growth. There are empirical studies that find the effects of finance on economic growth to be insignificant or even negative in some cases (Beck et al. 2014; Rousseau and Wachtel 2011). This supports recent research that finds banking sector depth to be positive to economic growth in the ASEAN economies (Pradhan et al. 2017). In the case of the ASEAN economies, the insignificant effects of financial markets can be explained by the more rapid development of the financial institutions sector compared to financial markets. Previous financial development and integration policies in the ASEAN region focused on stability as opposed to focusing on growth (Almekinders et al. 2015). As a result, this has led to a fragmented financial market that is insignificant to growth. The findings suggest that policymakers should continue to strengthen the financial institution sector and implement policies to further integrate the financial markets sector across the region to achieve growth and prosperity through deeper financial linkages.

Finally, the estimated results of the control variables provide expected signs and significance. Human capital is significant and positive to economic growth, which is consistent with endogenous growth theories (Barro 1991; Mankiw et al. 1992). This is interesting as the ASEAN economies are diverse in its labour workforce in terms of languages spoken across the region especially when considering the movement of workers. The ASEAN economies encompass over 1000 different dialects with individual member states having more than one official language that includes English, Filipino, Indonesian, Khmer, Lao, Malay, Putonghua, Burmese, Spanish, Tamil, Thai and Vietnamese. Some studies find that human capital can be insignificant to growth when foreign language proficiency is not taken into account (Neycheva 2013). However, the ASEAN economies still practice English as an official language and most tertiary education systems in the region are conducted in the English language (ASEAN Secretariat 2018). Furthermore, many previous studies suggest that human capital is essential in enhancing the productivity of an economy and promotes technological progress that can spill over to other sectors in the economy (Oyinlola and Adedeji 2019; Zhou 2018). Focusing on the coefficients of hc, it can be observed that human capital accounts for over $20 \%$ of real GDP per labour growth across the sets of regressions. Thus, policymakers in the ASEAN economies should continue to implement policies that promote human capital development to increase economic growth.

Meanwhile, the estimated results show that openness to trade is positive and significant to economic growth. This supports many previous and recent studies that examine the effects of trade on economic growth (Anwar and Sun 2016; Darku and Yeboah 2018; Kheng et al. 2017). Traditionally, the ASEAN economies have relied on an export-oriented strategy for economic growth and as such, should continue to support trade liberalisation policies (Lee and Tan 2006). Openness to trade can further increase growth as it encourages foreign direct investments that can lead to spillover effects on the real economy, while reducing poverty through technology transfer and capital investments (Fowowe and Shuaibu 2014; Jiang 2012). 
Policymakers in the ASEAN economies should continue to identify and implement policies to encourage further intra-regional trade agreements which will have positive spillover effects on growth. Finally, population density, pop, presents mixed findings as it is insignificant in some of the specifications. In theory, the effects of population on economic growth are complex, as on the one hand, excessive population growth can be detrimental as it leads to an increase in consumption which lower investments in capital formation (Coale and Hoover 1958). Meanwhile, other economies, such as Singapore, suffer from a drop in fertility which reduces the amount of active labourer to people resulting in lower growth (Bloom and Williamson 1998). In the case of the ASEAN economies, this may be insignificant due to the diverse population growth of the individual member states.

\section{Concluding remarks}

There is vast empirical evidence that supports the role of finance and institutions in spurring economic growth. However, in recent years there is a body of literature that suggests a weakening relationship between financial development and economic growth, due to excessive financial liberalisation alongside the absence of strong institutional. The ASEAN economies have grown considerably since its inception in 1967 and have the potential for further economic growth. Despite experiencing the brunt of the Asian Financial Crisis, the region has recovered and has continued to grow. The ASEAN economies continue to integrate over the last two decades, implementing policies to liberalise trade, encourage cross-border banking and promote financial linkages. Previous empirical studies examining the ASEAN economies suggest that trade and export-oriented strategies play an essential role in the region's growth. Although trade can promote economic growth through technological spillovers and capital investments, it can potentially be unsustainable in the longrun as the transfer of technology is disembodied and these investments will converge to its steady states. As a result, policymakers have begun to implement initiatives to develop the region through the ASEAN Economic Community Blueprint that involves regional efforts to advance financial development and integration alongside the development of sound institutions.

This study examines the role of financial structures and institutional development on economic growth in the ASEAN economies from 1995 to 2017 using a dynamic panel estimator. This study differs from previous examinations between finance and growth as it employs financial development indices proposed by Svirydzenka (2016), which distinguishes financial institutions and markets while considering the accessibility, efficiency and depth of the respective financial structure. The use of the financial development indices differs from many previous studies that examine the effects of bank-based and market-based financial systems on economic growth, which usually focuses on specific characteristics of the financial structure such as banking-depth. As a result, this study provides new evidence on the role of financial structures in economic growth using financial development variables that provides a more complete measure. 
In general, the estimated results show that financial and institutional development has a positive and significant impact on economic growth, supporting previous studies in the literature. However, the estimated results show that financial institutions are positive and significant to economic growth, while financial markets are insignificant. On the one hand, these findings support the view that postulates the weakening effects of finance on growth (Nain and Kamaiah 2014; Rousseau and Wachtel 2011). Yet the insignificance of financial markets on growth can be explained by previous studies, which find financial markets to be weaker and negative in the short-run (Gaffeo and Garalova 2014). In this case, stock market development is lagging behind in the ASEAN economies as financial institutions are still dominant in the region.

On the other hand, the significant effects of financial institutions suggest that further financial development and integration in the ASEAN economy is essential in order to promote economic growth (Dutta and Mukherjee 2018). Additionally, the study finds the rule of law to be positive and significant towards economic growth which is expected and supports many previous empirical works (La Porta et al. 2000). More interestingly, the rule of law is complementary to financial development as the interaction terms of financial institutions and markets with the rule of law is significant and positive to economic growth. This supports previous empirical studies that highlight the complementary role of finance and institutions on economic growth (Aluko and Azeez 2018; Pattanaik and Nayak 2014).

There are a number of policy implications for the study. Policymakers in the region should continue to further develop and integrate financial markets within the region, which can potentially spur economic growth in the ASEAN economies. Currently, the development of financial markets in the ASEAN economies is lagging behind when compared with financial institutions. As a result, policymakers should continue to advance the sector to ensure that financial markets are further integrated between the ASEAN economies while advancing efforts on developing capital markets that will connect the region with the world. This is important as the financial markets in the region are underdeveloped with the exception of Singapore. Thus, stronger integration in the region will encourage the free flow of capital between the member states and contribute to the goal of achieving an ASEAN Economic Community.

Furthermore, although financial institutions contribute to growth in the region, policymakers should identify an optimal level of financing and establish supervisory institutions that can monitor financial institutions across the region. This is important particularly with the implementation of the Qualified ASEAN Banks, which can dramatically increase financial development in the region. Financial liberalisation policies such as these can potentially lead to excessive financialisation particularly when economies lack institutional development. In general, the ASEAN economies have benefitted from finance and institutional development and have the potential to further increase growth. As such, the financial integration policies that ASEAN policymakers have introduced should continue as it has the potential to increase growth while considering further financial sector and institutional reforms.

There are a number of directions for future work. Although the econometric methodology employed in this study is sound, policymakers may be interested in 
the effects of financial and institutional development of the individual member's states. This is of interest as the ASEAN economies are diverse in its economic development. For example, Singapore has a mature financial market, while the other ASEAN economies lag behind in development. Meanwhile, Cambodia, Lao PDR, Myanmar and Viet Nam, all lag behind in terms of overall financial and institutional development. Employing econometric strategies such as time-series methodology can provide further inferences on the effect of finance and institutions on the individual ASEAN economies.

Acknowledgements The author acknowledges the direction of the handling director and the suggestions provided by the two anonymous referees. The usual disclaimer applies.

\section{Compliance with ethical standards}

Conflict of interest No potential conflict of interest was reported by the author.

Open Access This article is licensed under a Creative Commons Attribution 4.0 International License, which permits use, sharing, adaptation, distribution and reproduction in any medium or format, as long as you give appropriate credit to the original author(s) and the source, provide a link to the Creative Commons licence, and indicate if changes were made. The images or other third party material in this article are included in the article's Creative Commons licence, unless indicated otherwise in a credit line to the material. If material is not included in the article's Creative Commons licence and your intended use is not permitted by statutory regulation or exceeds the permitted use, you will need to obtain permission directly from the copyright holder. To view a copy of this licence, visit http://creativecommons.org/licen ses/by/4.0/.

\section{References}

Almekinders G, Fukuda S, Mourmouras A, Zhou J, Zhou YS (2015) ASEAN financial integration. International Monetary Fund, IMF working papers WP/15/34 Washington, DC

Aluko OA, Azeez BA (2018) Effectiveness of legal institutions in stock market development in sub-Saharan Africa. Econ Change Restruct 52(4):439-451

Anwar S, Sun S (2016) Foreign direct investment, domestic sales and exports of local firms: a regional perspective from China. J Asia Pac Econ 21(3):325-338

Arellano M, Bond S (1991) Some tests of specification for panel data: Monte Carlo evidence and an application to employment equations. Rev Econ Stud 58(2):277-297

Arestis P, Demetriades PO, Luintel KB (2001) Financial development and economic growth: the role of stock markets. J Money Credit Bank 33(1):16-41

ASEAN Secretariat (2008) ASEAN economic community blueprint. Jakarta, ASEAN Secretariat

ASEAN Secretariat (2018) ASEAN stats data portal

Barro RJ (1991) Economic growth in a cross-section of countries. Q J Econ 106(2):407-443

Beck T (2015) Cross-border banking and financial deepening: the African experience. J Afr Econ 24(Sup 1):i32-i45

Beck T, Levine R (2002) Industry growth and capital allocation: does having a market- or bank-based system matter? J Financ Econ 64(2):147-180

Beck T, Demirgüç-Kunt A, Laeven L, Levine R (2008) Finance, firm size and growth. J Money Credit Bank 40:1379-1405

Beck T, Degryse H, Kneer C (2014) Is more finance better? Disentangling intermediation and size effects of financial system. J Financ Stab 40:50-64

Berggren N, Jordahl H (2005) Does free trade really reduce growth? Further testing using the economic freedom index. Public Choice 122(1-2):99-114 
Bloom DE, Williamson JG (1998) Demographic transition and economic growth miracles in emerging Asia. World Bank Econ Rev 12:419-455

Blundell R, Bond S (1998) Initial conditions and moment restrictions in dynamic panel data models. J Econ 87(1):115-143

Breitenlechner M, Gächter M, Sindermann F (2015) The finance-growth nexus in crisis. Econ Lett 132:31-33

Chakraborty S, Ray T (2006) Bank-based versus market-based financial systems: a growth-theoretic analysis. J Monet Econ 53(2):329-350

Coale AJ, Hoover EM (1958) Population growth and economic development in low-income countries: a case study of India's prospects. Princeton University Press, Princeton

Cull R, Xu LC (2013) Job growth and finance: are some financial institutions better suited to the early stages of development than others? World Bank Econ Rev 27(3):542-572

Darku AB, Yeboah R (2018) Economic openness and income growth in developing countries: a regional comparative analysis. Appl Econ 50(8):855-869

Deidda L, Fattouh B (2008) Banks, financial markets and growth. J Financ Intermed 17(1):6-36

Demirgüç-Kunt A, Maksimovic V (2002) Funding growth in bank-based and market-based financial systems: evidence from firm-level data. J Financ Econ 65(3):337-363

Dutta N, Mukherjee D (2018) Can financial development enhance transparency? Econ Change Restruct 51(4):279-302

Feenstra RC, Robert I, Timmer MP (2015) The next generation of the Penn World Table. Am Econ Rev 105(10):3150-3182

Fowowe B (2013) Financial liberalisation in Sub-Saharan Africa: what do we know? J Econ Surv 27:1-37

Fowowe B, Shuaibu MI (2014) Is foreign direct investment good for the poor? New evidence from African countries. Econ Change Restruct 47(4):321-339

Gaffeo E, Garalova P (2014) On the finance-growth nexus: additional evidence from Central and Eastern Europe countries. Econ Change Restruct 47(2):89-115

Goldsmith RW (1969) Financial structure and development. Yale University Press, New Haven

Haggard S, Tiede L (2011) The rule of law and economic growth: where are we? World Dev 39(5):673-685

Haini H (2019) Internet penetration, human capital and economic growth in the ASEAN economies: evidence from a translog production function. Appl Econ Lett 26(21):1774-1778

Henningsen A, Henning CHCA (2009) Imposing regional monotonicity on translog stochastic production frontiers with a simple three-step procedure. J Prod Anal 32(3):217-229

Ho SY, Iyke BN (2018) Finance-growth-poverty nexus: a re-assessment of the trickle-down hypothesis in China. Econ Change Restruct 51(3):221-247

Hondroyiannis G, Lolos S, Papapetrou E (2005) Financial markets and economic growth in Greece, 19861999. J Int Financ Mark Inst Money 15(2):173-188

Huybens E, Smith B (1999) Inflation, financial markets, and long-run real activity. J Monet Econ 43:283-315

Jiang Y (2012) An empirical study of openness and convergence in labor productivity in the Chinese provinces. Econ Change Restruct 45(4):317-336

Kaufmann D, Kraay A, Mastruzzi M (2010) The worldwide governance indicators: methodology and analytical issues. World Bank Development Research Group, Policy research working paper WPS5430, Washington, DC

Khandker A (2016) Why is the South Korean growth experience different? An analysis of the differences of per capita GDP between South Korea and South Asian countries. Econ Change Restruct 49(1):41-69

Kheng V, Sun S, Anwar S (2017) Foreign direct investment and human capital in developing countries: a panel data approach. Econ Change Restruct 50(4):341-365

King RG, Levine R (1993) Finance, entrepreneurship and growth. J Monet Econ 32(3):513-542

Krugman P (1994) The myth of Asia's miracle. Foreign Aff 79(November-December):62-78

La Porta R, Lopez-de-Silanes F, Shleifer A, Vishny RW (1998) Law and finance. J Polit Econ 106(6):1113-1155

La Porta R, Lopez-de-Silanes F, Shleifer A, Vishny RW (2000) Investor protection and corporate governance. J Financ Econ 58:3-29

La Porta R, Lopez-de-Silanes F, Shleifer A (2008) The economic consequences of legal origins. J Econ Lit 46(2):285-332

Lee HH, Tan HB (2006) Technology transfer, FDI and economic growth in the ASEAN region. J Asia Pac Econ 11(4):394-410

Levine R (1997) Financial development and economic growth: views and agenda. J Econ Lit 35(2):688-726

Levine R, Zervos S (1998) Stock markets, banks, and economic growth. Am Econ Rev 88(3):537-558 
Levine R, Loayza N, Beck T (2000) Financial intermediation and growth: causality and causes. J Monet Econ 46(1):31-77

Mankiw NG, Romer D, Weil DN (1992) A contribution to the empirics of economic growth. Q J Econ 107(2):407-437

Masron TA (2017) Relative institutional quality and FDI inflows in ASEAN countries. J Econ Stud 44(1):115-137

Morck R, Nakamura M (1999) Banks and corporate control in Japan. J Finance 54:319-340

Nain MZ, Kamaiah B (2014) Financial development and economic growth in India: some evidence from non-linear causality analysis. Econ Change Restruct 47(4):299-319

Neycheva M (2013) Does higher level of education of the labor force cause growth? Evidence from Bulgaria. Econ Change Restruct 46(3):321-339

Nguyen G (2018) Changes in the distribution of household consumption in Southeast Asia. Econ Change Restruct. https://doi.org/10.1007/s10644-018-9236-7

Nicolas F (2008) The political economy of regional integration in East Asia. Econ Change Restruct 41(4):345-367

Oyinlola MA, Adedeji A (2019) Human capital, financial sector development and inclusive growth in subSaharan Africa. Econ Change Restruct 52(1):43-66

Patrick H (1966) Financial and economic growth in underdeveloped countries. Econ Dev Cult Change 14:174-189

Pattanaik F, Nayak NC (2014) Economic freedom and economic growth in India: what is the empirical relationship. Econ Change Restruct 47(4):275-298

Peia O, Roszbach K (2015) Finance and growth: time series evidence on causality. J Financ Stab 19:105-118

Petri PA, Plummer MG, Zhai F (2012) ASEAN economic community: a general equilibrium analysis. Asian Econ J 26(2):93-118

Pradhan RP, Arvin MB, Hall JH, Norman NR (2017) ASEAN economic growth, trade openness and banking-sector depth: the nexus. EconomiA 18(3):359-379

Prasad ES, Rajan RG (2008) A pragmatic approach to capital account liberalization. J Econ Perspect 22(3): $149-172$

Rajan RG (1992) Insiders and outsiders: the choice between informed and arm's-length debt. J Finance 47:1367-1400

Rillo AD (2018) ASEAN financial integration: opportunities, risks, and challenges. Public Policy Rev 14(5):901-924

Rodrik D (2000) Institutions for high-quality growth: what they are and how to acquire them? Stud Comp Int Dev 35(3):3-31

Romer P (1990) Endogenous technological change. J Polit Econ 98(5):71-101

Rousseau PL, Wachtel P (2011) What is happening to the impact of financial deepening on economic growth? Econ Inq 49(1):276-288

Santiago R, Fuinhas JA, Marques AC (2018) The impact of globalization and economic freedom on economic growth: the case of the Latin America and Caribbean countries. Econ Change Restruct. https:// doi.org/10.1007/s10644-018-9239-4

Sargan J (1958) The estimation of economic relationships using instrumental variables. Econometrica 26(3):393-415

Scharfstein D (1988) The disciplinary role of takeovers. Rev Econ Stud 55:185-199

Schumpeter JA (1911) The theory of economic development. Harvard University Press, Cambridge

Sharma R, Bardhan S (2017) Finance growth nexus across Indian states: evidences from panel cointegration and causality tests. Econ Change Restruct 50(1):1-20

Solow RM (1956) A contribution to the theory of economic growth. Q J Econ 70(1):65-94

Stiglitz JE (1985) Credit markets and the control of capital. J Money Credit Bank 17:133-152

Strieborny M, Kukenova M (2015) Investment in relationship-specific assets: does finance matter? Rev Finance 20(4):1487-1515

Stulz RM (2002) Financial structure, corporate finance, and economic growth. In: Demirguc-Kunt A, Levine R (eds) Financial structure and economic growth: cross-country comparisons of banks, markets, and development. MIT Press, Cambridge, pp 143-188

Svirydzenka K (2016) Introducing a new broad-based index of financial development. International Monetary Fund, IMF working papers WP/16/5 Washington, DC

Thanoon MAM, Baharumshah AZ (2005) What happened to savings during the financial crisis: a dynamic panel analysis of Asian-5 countries. Econ Change Restruct 38(3-4):257-275

World Bank (Various Years) World Development Indicators 
World Bank (Various Years) World Governance Indicators

Zhou Y (2018) Human capital, institutional quality and industrial upgrading: global insights from industrial data. Econ Change Restruct 51(1):1-27

Publisher's Note Springer Nature remains neutral with regard to jurisdictional claims in published maps and institutional affiliations. 